\title{
Field lethal incubation temperature of olive ridley sea turtle Lepidochelys olivacea embryos at a mass nesting rookery
}

\author{
Roldán A. Valverde ${ }^{1, *}$, Susanna Wingard ${ }^{1}$, Flor Gómez ${ }^{2}$, \\ Mark T. Tordoir ${ }^{3}$, Carlos M Orrego ${ }^{4}$ \\ ${ }^{1}$ Department of Biological Sciences, Southeastern Louisiana University, Hammond, Louisiana 70402, USA \\ ${ }^{2}$ Universidad Nacional San Antonio Abad del Cusco, Cusco, Perú \\ ${ }^{3}$ Department of Environmental Sciences, Van Hall Institute, Leeuwarden, Netherlands \\ ${ }^{4}$ Department of Bioscience and Biotechnology, Drexel University, Philadelphia, Pennsylvania 19104, USA
}

\begin{abstract}
Hatching success in olive ridley mass nesting arribada beaches is typically low. We conducted a short study to understand whether incubation temperature in dry months accounts for exceedingly low hatching success at Ostional Beach, Costa Rica, a mass nesting rookery. We measured in situ incubation temperatures in nests from 4 arribadas recorded in October to December 2008, and January 2009. Mean incubation temperatures for all months exceeded the upper lethal limit of $35^{\circ} \mathrm{C}$, and no nests produced hatchlings when incubated at this or higher temperatures. Embryo development was inversely related to mean incubation temperature. Hatching success was low $(2 \%)$ for the study period, and only 5 of 37 marked nests produced hatchlings. Mean incubation temperature for successful nests was $<35^{\circ} \mathrm{C}$. Since incubation temperatures of $32^{\circ} \mathrm{C}$ and higher recorded during the gonadal thermosensitive period were above the mean pivotal temperature of $30.5^{\circ} \mathrm{C}$, the few hatchlings produced were presumably female. Incubation temperatures were significantly higher during the second and third trimesters of incubation during all months as a result of metabolic heating. However, during January to March when embryos did not develop, higher incubation temperatures of in situ nests relative to controls indicated that heating was a result of microbial activity associated with egg decomposition. Our study demonstrates that after the onset of the dry season, incubation temperatures at this beach become lethal.
\end{abstract}

KEY WORDS: Olive ridley $\cdot$ Lepidochelys olivacea $\cdot$ Ostional $\cdot$ Incubation temperature $\cdot$ Precipitation · Thermal tolerance range $\cdot$ Field lethal temperature $\cdot$ Arribada $\cdot$ Mass nesting

\section{INTRODUCTION}

The reproductive fitness of sea turtle females largely depends on their selection of nesting beach and the quality and timing of their nesting activities (Miller 1997). During incubation, the nests are affected by biotic factors such as predation (Eckrich \& Owens 1995) and microorganism decomposers (Madden et al. 2008), and abiotic factors such as temperature and moisture (Ackerman 1997), density-dependent factors (Honarvar et al. 2008) and respiratory gas fluxes (Wallace et al. 2004). Of all these factors, temperature plays a criti- cal role in embryo development (Miller 1985). When incubated at a constant temperature, sea turtle embryo development occurs within a thermal tolerance range (TTR) of $25-27$ to $33-35^{\circ} \mathrm{C}$, above or below which embryo development is impaired (Ackerman 1997). Like crocodiles and many other reptiles, sea turtles exhibit temperature-dependent sex determination (TSD; Yntema \& Mrosovsky 1980, Janzen \& Paukstis 1991), which is characterized by the exclusive production of a single sex below (male) or above (female) a transitional range of temperatures (TRT; Mrosovsky 1994, Wibbels 2003). Within the TRT, sex production is variable and 
relative to incubation temperature and includes a pivotal temperature (PT) where the sex ratio is $1: 1$ (Mrosovsky \& Pieau 1991). PTs may vary inter- and intra-specifically, which implies that temperaturerelated studies need to be conducted at a population level (Wibbels 2003). Turtle sex is determined during a gonadal thermosensitive period (Mrosovsky \& Pieau 1991), which occurs in the second trimester of embryo development (Merchant-Larios et al. 1997). Studies have shown that the mean PT for olive ridley arribada populations nesting on Costa Rican Pacific northwest coast is $30.5^{\circ} \mathrm{C}$, the highest among sea turtles (McCoy et al. 1983, Wibbels et al. 1998). These characteristics make embryo development under high nest density conditions vulnerable to changes in environmental temperature, especially when incubation temperatures fluctuate around the PT, where a change of $3^{\circ} \mathrm{C}$ or less may result in the exclusive production of a single sex (Ewert et al. 1994, Wibbels 2003). Thus, understanding the relationship between incubation temperature, developmental stage and hatchling sex ratios is crucial for effective sea turtle conservation and management.

Olive ridley sea turtles Lepidochelys olivacea, and to a lesser extent the Kemp's ridley L. kempii, are unique in that in addition to nesting in solitary fashion like other sea turtles, many females also aggregate and arrive synchronously over a period of a few nights to nest by the thousands to tens of thousands on a small section of beach during events known as arribadas (Bernardo \& Plotkin 2007). Large arribadas surpassing 50000 females per event are known to occur at Gahirmatha and Rushikulya in India (Pandav et al. 1994, Shanker et al. 2004), at La Escobilla in Mexico (Márquez-M. et al. 1996), and at Ostional in Costa Rica (Richard \& Hughes 1972), with smaller arribadas occurring elsewhere on Eastern Pacific beaches (Bernardo \& Plotkin 2007). The vast majority, 98 to $99 \%$, of the annual female nesting population is estimated to lay eggs at these arribada sites (Abreu-Grobois \& Plotkin 2008). Although production potential is extremely high at these beaches, the aggregation of individuals on the beach and near shore during these events makes populations vulnerable to anthropogenic threats such as egg poaching (Cornelius et al. 2007) and incidental capture of adults and juveniles by fisheries (Arauz et al. 1998, 1999, Frazier et al. 2007). In addition, developing turtle eggs at these beaches are also subject to high natural mortality due to density-dependent factors (Bernardo \& Plotkin 2007). This has both ecological and conservation implications concerning the importance of arribada beaches for the long term survival of this species, currently listed as vulnerable by the IUCN Red List (Abreu-Grobois \& Plotkin 2008).

High nest densities alone at arribada beaches are correlated with low hatching success (Honarvar et al.
2008). Additionally, natural embryo mortality is high during arribadas due to excavation of previously laid nests by later nesting females (Cornelius et al. 1991). It is this high loss of eggs that led Costa Rican authorities to legitimize a large-scale egg extraction and marketing program in which Ostional villagers collect as many eggs as possible during the first $36 \mathrm{~h}$ of each arribada to sell in the domestic market (Campbell 1998, Hope 2002, Campbell et al. 2007). Biologically, the large number of broken eggs fosters microbial populations on the beach, which use oxygen, in addition to that being consumed by the many developing embryos (Madden et al. 2008). $\mathrm{PO}_{2}$ is lower and incubation temperatures are higher in high density nests compared to low density nests as a result of microbial and embryo respiration and metabolic heating (Clusella-Trullas \& Paladino 2007, Honarvar et al. 2008). The extent of the influence of metabolic (embryonic and microbial) activity on incubation temperatures in areas with high nest density is poorly understood. However, mass mortality of ridley embryos during the dry, hot season has been suspected for years at Ostional (Cornelius et al. 1991). Accordingly, our main objective was to determine whether dry season incubation temperatures are lethal to olive ridley embryos at Ostional Beach, a mass nesting beach.

\section{MATERIALS AND METHODS}

Study site. Field work was conducted at Ostional Beach (9 $\left.9^{\circ} 59^{\prime} 46^{\prime \prime} \mathrm{N}, 85^{\circ} 42^{\prime} 13^{\prime \prime} \mathrm{W}\right)$, Costa Rica (Fig. 1) from late October 2008 to early March 2009. This dark

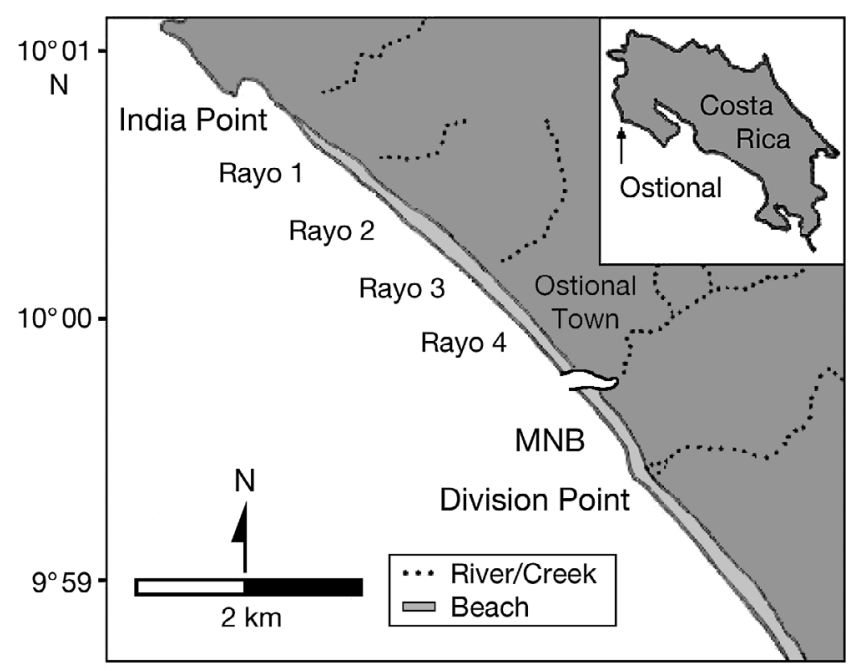

Fig. 1. Ostional Beach, Costa Rica. Sections (Rayo 1-4 and main nesting beach [MNB]) in which the beach was divided to facilitate the work. Typically, large arribadas occur at MNB, although in large events as in 2008 , the phenomenon may be spread over the entire beach 
sand beach is located within the Ostional Wildlife Refuge and measures $3.9 \mathrm{~km}$ in length. The region exhibits fairly well marked climate conditions with a rainy season that normally extends from May to November and a dry season that extends from December to April. The beach is divided into 5 sections and each section is divided into subsections marked with posts every $50 \mathrm{~m}$, which are located on the vegetation line. These sections are Rayo 1 (posts 1-17), Rayo 2 (posts 18-29), Rayo 3 (posts 30-40), Rayo 4 (posts 41-59) and main nesting beach (MNB; posts 60-78). Arribadas tend to concentrate on the main nesting beach. Only during large arribadas do nesting females crowd the beach to such an extent that the arribada encompasses most of the available beach sections. Arribadas peak in the rainy season (August to December), with the September, October and November arribadas being usually the largest, significantly decreasing in abundance the rest of the year (Cornelius 1986). Ostional Beach typically supports on average 11 arribadas each year and ranks second behind La Escobilla among the largest arribada assemblages, with between 50000 and 200000 nesting females per arribada (Plotkin 2007). Using the strip transect in time method (Valverde \& Gates 1999), arribadas in 2008 were estimated to fluctuate between an average of $117996 \pm 9395$ females (mean $\pm \mathrm{SE}_{\text {; }}$ September to November; $\mathrm{n}=2$ ) and an average of $8101 \pm 3573$ (January to July; $\mathrm{n}=9$ ) (R. A. Valverde unpubl.).

Precipitation and nest and sand temperatures. Daily precipitation $(\mathrm{mm})$ was recorded every morning (07:00 h) with a precipitation gauge throughout the study period. In situ nests were selected during the arribadas of October 28-30, November 21-23, and December 21-23 of 2008 and during January 22-23, 2009. Nest selection was conducted by choosing any female laying eggs in the open beach between the high tide mark and the vegetation line, which is the area of the beach most used by olive ridleys. Newly purchased HOBO pendant temperature data loggers (Onset Computer, UA-001-08, accuracy: $\pm 0.5^{\circ} \mathrm{C}$, resolution: $0.1^{\circ} \mathrm{C}$, according to manufacturer) were inserted into the center of each nest without disturbing the egg-laying process. Once nesting females began to fill the nest cavity, the turtles were removed so the nest could be covered and protected from subsequent nesters. Each nest was covered with a $40 \times 40 \times 25 \mathrm{~cm}$ wire mesh cage. From Day 40 of the incubation period, each nest was monitored daily for signs of neonate emergence and cages were either lifted or removed upon sighting of a hatchling. Nests were exhumed $3 \mathrm{~d}$ after the last observed neonate emerged, $\sim 50 \mathrm{~d}$ from oviposition. No live embryos were observed in the nests during exhumation.

Control data loggers were buried in the sand $(>1 \mathrm{~m}$ distance from nests) and set to record sand temperature throughout the entire incubation period of the respective arribada nests at a depth equal to that of the center of an average nest (30 to $35 \mathrm{~cm}$ ). All data loggers were programmed to collect temperature data every $2 \mathrm{~h}$. Recording consistency and accuracy of data loggers were ensured by placing all sensors in a bag simultaneously and keeping them in a shaded room to record air temperature for a period of $38 \mathrm{~h}$ (recordings included 2 night periods).

Nest development and hatching success. Upon exhumation, data loggers were retrieved and the developmental stage in each egg was recorded for all nests. Eggs were classified into developmental stages according to Chacón et al. (2007): Stage 0 (no apparent embryonic development), Stage I (embryo fills 1 to $25 \%$ of amniotic cavity), Stage II (26-50\%), Stage III (51-75\%), Stage IV (76-100\%), Stage V (empty egg shells from hatched turtles). Eggs with indeterminable development were classified as 'unknown stage of development' (USD). Given the relatively few marked nests with data loggers, we decided to increase the sample size of nests in the study by excavating additional $1 \mathrm{~m}^{2}$ plots (10 m due north or south of each study nest) concurrent with exhumations of the study nests from October and November 2008. The number of nests and each egg's developmental stage was recorded for each $1 \mathrm{~m}^{2}$ plot.

Data analysis. Data from nest and control data loggers were downloaded and converted to spreadsheets using HOBOware Pro 2.7.3. Temperature recordings of data loggers were checked for consistency by testing the hypothesis that the individual readings were no different from the mean by running a $\chi^{2}$ test for each of the time points over a $38 \mathrm{~h}$ period (Fig. 2). No significant differences were found.

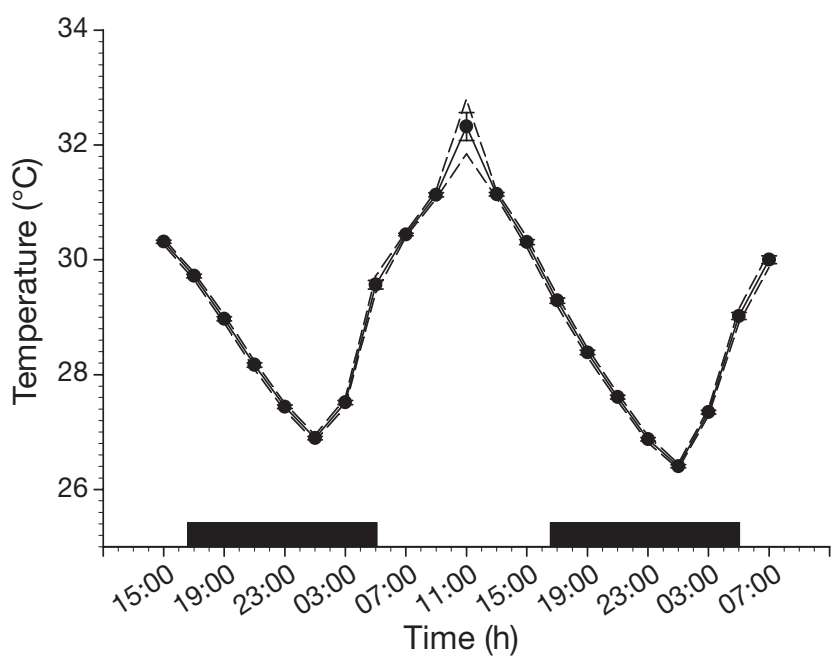

Fig. 2. Mean $( \pm \mathrm{SE})$ air temperature and upper and lower confidence intervals $(95 \%)$ observed in all data loggers $(n=21)$ kept in the shade for $38 \mathrm{~h}$. Black bars on $x$-axis: scotophase. Individual logger temperatures were not significantly different from their respective mean $\left(\chi^{2}=45.31, \mathrm{df}=20, \mathrm{p}<0.001\right)$ 
Daily mean incubation temperatures were calculated for the incubation period for all nests and controls. Monthly and trimester mean incubation temperatures were also calculated. Hatching success was calculated for each nest as: (empty egg shells)/(total number of eggs) $\times 100 \%$. Data analysis was conducted with Systat 10.2 using a 2-sample t-test, 2-way ANOVA, and regression analyses. For all tests, $\alpha=0.05$. After completing a preliminary analysis, we reviewed our data and found no outliers. We tested the residuals for normality using a 1-sample KS test with Lilliefor's option and homogeneity of variance, and fit a model by analyzing the plot of residuals against predicted values.

\section{RESULTS}

\section{Precipitation}

In general, monthly average precipitation was 3.69 , $2.13,0.08,0.0,0.0,0.0,0.10 \mathrm{~mm} \mathrm{~d}^{-1}$ for the months of October to April, respectively. Specifically, precipitation throughout the incubation period (October 29 to March 8) was low on average with $1.25 \mathrm{~mm} \mathrm{~d}^{-1}$. Of the $131 \mathrm{~d}$ in the study period, $118 \mathrm{~d}(90 \%)$ were without precipitation and total precipitation for that period was $158.10 \mathrm{~mm}$. Rainfall, when it occurred, only exceeded $3 \mathrm{~mm}$ on 3 occasions in the entire study period: November $9(52 \mathrm{~mm})$ and $30(57 \mathrm{~mm})$, and December 1 (33 mm). Overall, the dry season started a month early with November precipitation being lower than its mean precipitation for the period 1995-2007 (Fig. 3). This precipitation and associated cloudiness led to relatively abrupt and brief decreases in mean incubation temperature of $1.5,2$ and $1.3^{\circ} \mathrm{C}$, respectively (Fig. 4). No historical records for air temperature were available for the area.

\section{Nest temperatures}

A total of 42 data loggers were deployed in arribada nests during the study. Loggers were placed in nests distributed throughout the beach (Rayo 1 to MNB) between the high tide and away from vegetation and estuaries, which represents the bulk of the incubation environment in Ostional. Due to logistic problems, we were able to record incubation temperatures from only 37 nests. Excluded from analyses were data loggers that could not be relocated (December, $\mathrm{n}=2$ ), prematurely stopped recording, did not record any data (November, $\mathrm{n}=2$ ), or were excavated by raccoons (January, $n=1$ ). Daily mean $( \pm \mathrm{SE})$ incubation temperatures are shown in Fig. 4. The mean incubation tem-

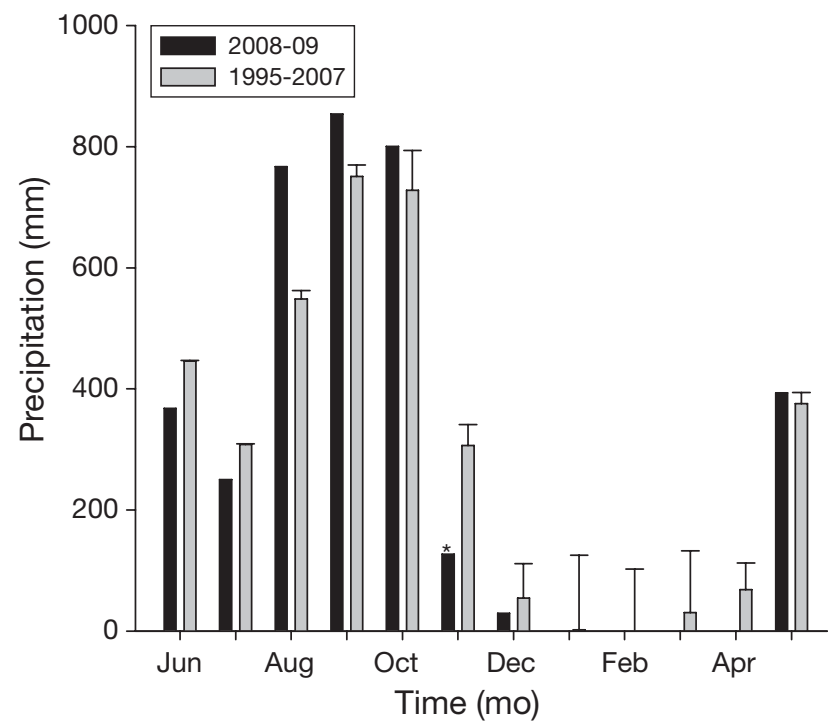

Fig. 3. Mean $( \pm \mathrm{SE})$ total monthly precipitation recorded at Nosara Beach (adjacent to study site; gray bars) for 19952007 and total precipitation at Ostional Beach (dark bars) for 2008-2009. Data shows the dry season (Dec-Mar) and rainy season (May-Nov). November 2008 (*) was drier than average

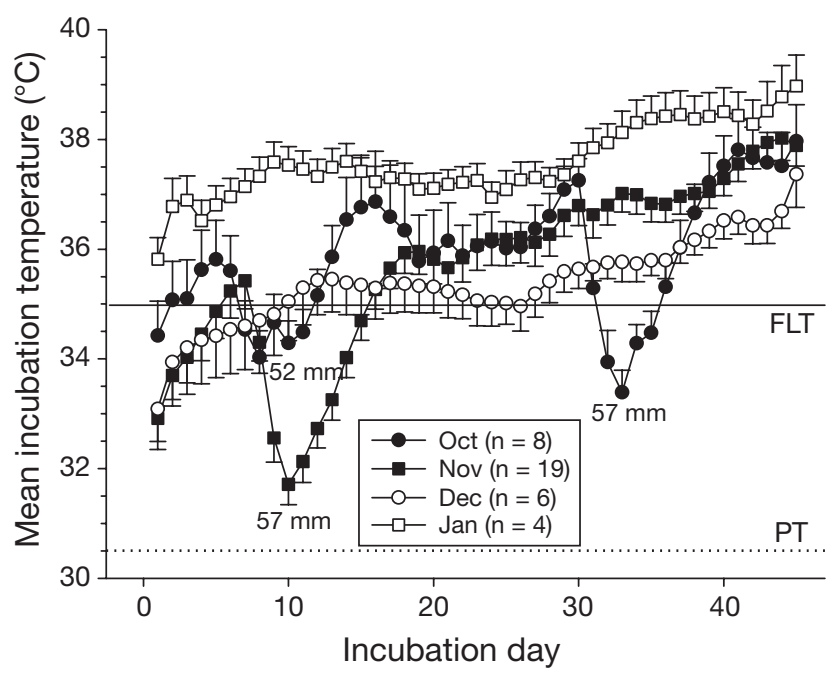

Fig. 4. Mean $( \pm \mathrm{SE})$ daily incubation temperatures for nests laid during arribadas of Oct, Nov, and Dec 2008, and Jan 2009. Days with precipitation $>3 \mathrm{~mm}$ are annotated. $\mathrm{PT}=$ mean pivotal temperature; FLT $=$ field lethal temperature

perature for October nests was $35.90^{\circ} \mathrm{C}$ (mean minimum and maximum: 34.17 and $37.66^{\circ} \mathrm{C}$, respectively; $\mathrm{n}=8)$, for November was $35.67^{\circ} \mathrm{C}\left(32.99-38.16^{\circ} \mathrm{C} ; \mathrm{n}=\right.$ 19), for December was $35.39^{\circ} \mathrm{C}\left(34.23-37.06^{\circ} \mathrm{C} ; \mathrm{n}=6\right)$, and for January nests it was $37.58^{\circ} \mathrm{C}\left(36.85-38.26^{\circ} \mathrm{C}_{i}\right.$ $\mathrm{n}=4$ ). Incubation period lasted about $47 \mathrm{~d}$, which is when the last hatchling was observed.

The total range in recorded temperatures for the entire study period was $17.49^{\circ} \mathrm{C}\left(\mathrm{min} .=25.03^{\circ} \mathrm{C}\right.$, 
$\max .=42.52^{\circ} \mathrm{C} ;$ both temperatures recorded in October nesters). Mean daily nest temperatures ranged from $28.41^{\circ} \mathrm{C}$ in November to $40.14^{\circ} \mathrm{C}$ in January. Incubation temperature was not related to the beach sector where nests were laid, as there was no significant relationship between mean incubation temperature and nest location by beach section. Study nests in adjacent sections of beach exhibited mean temperatures that differed by 0.30 to $2.68^{\circ} \mathrm{C}$, indicating that the thermal microenvironment was heterogeneous. Mean incubation temperatures in nests laid in January were significantly higher than in all other months, $37.58^{\circ} \mathrm{C}$ compared to $35.68^{\circ} \mathrm{C}$, respectively $(F=6.02 \mathrm{p}=0.00083$, Fig. $5 \mathrm{~B})$. Ranges in mean temperatures between clutches was $5.17^{\circ} \mathrm{C}$ for nests laid during the November arribada, the month with the greatest inter-nest temperature variability as well as lowest mean incubation temperature in a nest $\left(32.99^{\circ} \mathrm{C}\right)$. Mean incubation temperatures were most uniform among nests laid during the January arribada (range of $1.42^{\circ} \mathrm{C}$ ). One January nest had the highest mean incubation temperature of $38.26^{\circ} \mathrm{C}$. Nest temperatures generally increased throughout the incubation period. Mean incubation temperatures for the second $\left(36.11^{\circ} \mathrm{C}\right)$ and third $\left(36.97^{\circ} \mathrm{C}\right)$ trimesters were significantly higher than in the first $\left(34.57^{\circ} \mathrm{C}, F=9.75, \mathrm{p}=0.00014\right.$; Fig. 5A). Incubation temperatures $<35^{\circ} \mathrm{C}$, the upper limit of the TTR (Ackerman 1997), only occurred in the first trimesters of nests laid in November $\left(33.74^{\circ} \mathrm{C}\right)$ and December $\left(34.70^{\circ} \mathrm{C}\right)$. Though no month had mean temperatures below the upper lethal limit of $35^{\circ} \mathrm{C}$, several nests laid in October $(\mathrm{n}=2)$, November $(\mathrm{n}=5)$, and December $(\mathrm{n}=3)$ had mean temperatures $<35^{\circ} \mathrm{C}$. Mean daily temperatures exceeded $35^{\circ} \mathrm{C}$ for an average $69 \%$ of the incubation period of all nests (30.95 d,
$95 \%$ confidence interval $\left[\mathrm{CI}_{95 \%}\right] 26.78$ to $35.12 \mathrm{~d}_{\text {; }}$ means and SE are reported in figures to increase figure clarity), and mean temperatures for all nests laid in January exceeded $35^{\circ} \mathrm{C}$ throughout the entire incubation period.

\section{Control temperatures}

Temperatures in controls (Fig. 6) increased significantly toward the end of the study period. Mean temperatures in January controls $\left(36.14^{\circ} \mathrm{C}, \mathrm{CI}_{95} \% 34.50\right.$ to $37.27^{\circ} \mathrm{C}$ ) were significantly higher than those in November $\left(34.09^{\circ} \mathrm{C}, \mathrm{CI}_{95 \%} 32.63\right.$ to $35.55^{\circ} \mathrm{C}$; 2 -sample $t$-test, $t=2.85, \mathrm{p}=0.017$ ).

\section{Nest versus control temperatures}

Mean incubation temperatures from nests laid in November $\left(35.67^{\circ} \mathrm{C}, \mathrm{CI}_{95 \%} 34.91\right.$ to $\left.36.43^{\circ} \mathrm{C}\right)$ were significantly higher than their respective controls $\left(34.10^{\circ} \mathrm{C}, \mathrm{CI}_{95 \%} 32.63\right.$ to $35.55^{\circ} \mathrm{C}, t=2.193, \mathrm{p}=0.039$ ). Temperatures within nests were on average $1.57^{\circ} \mathrm{C}$ warmer than those in controls. The difference increased with each trimester, with nests being 0.66 , 1.76 , and $2.23^{\circ} \mathrm{C}$ warmer than controls for the first to third trimesters, respectively (Fig. 6A). There was a significant difference between mean temperatures in controls $\left(36.14^{\circ} \mathrm{C}, \mathrm{CI}_{95} \% 35.00-37.27^{\circ} \mathrm{C}\right)$ and in nests (37. $58^{\circ} \mathrm{C}, \quad \mathrm{CI}_{95 \%} 36.45-38.70^{\circ} \mathrm{C}$ ) laid in January (Fig. 6B; $t=2.320, \mathrm{p}=0.049$ ). January nests were on average $1.47^{\circ} \mathrm{C}$ warmer than controls, though they did not become increasingly warmer throughout the incubation period $\left(1.32,1.26\right.$, and $1.79^{\circ} \mathrm{C}$, for the first to third trimesters, respectively).

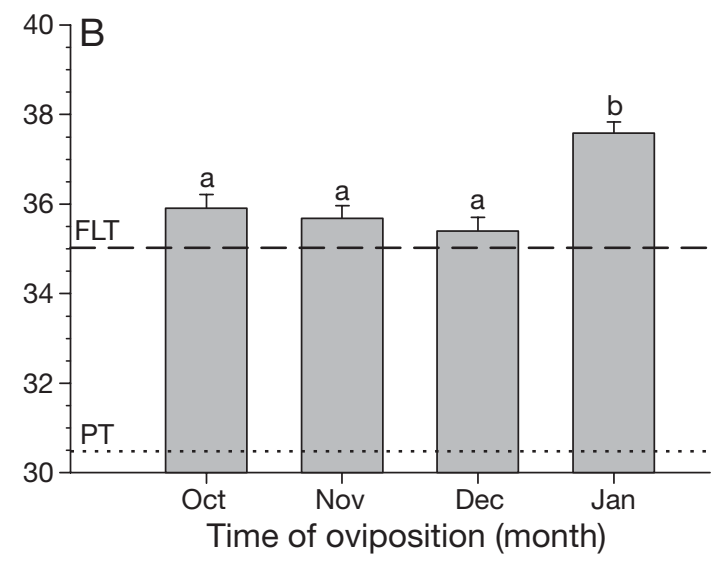

Fig. 5. Mean $( \pm$ SE) incubation temperature per (A) trimester and (B) month of oviposition. Mean temperatures were significantly higher during 2nd and 3rd trimesters and during the entire incubation period for nests laid in January (pairwise comparison, Bonferroni adjusted means). Lowercase letters above bars indicate significant differences at $95 \%$ level of confidence. See Fig. 4 for definitions 


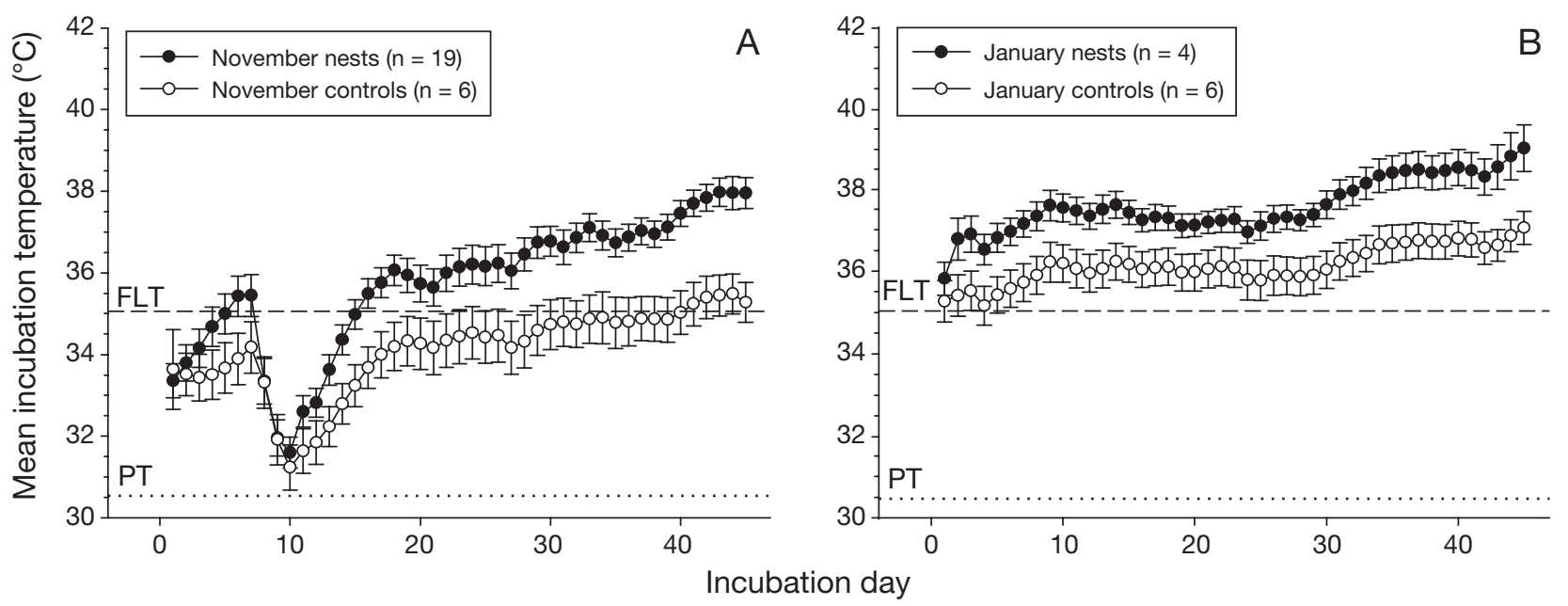

Fig. 6. Mean $( \pm$ SE) incubation temperatures of nests and controls from (A) November and (B) January. See Fig. 4 for definitions

\section{Embryo development and hatching success in study nests}

Of the 37 nests with usable data loggers, 16 nests exhibited no development. Hatching rates for study nests were $2.14 \%$ (19 of 889 eggs) for October, $2.54 \%$ (44 of 1646 eggs) for November, $1.72 \%$ (10 of 580 eggs) for December, and 0\% (0 of 439) for January, for an overall hatching rate of $2 \%$ (73 hatchlings out of 3554 eggs).

In order to study the effect of incubation temperature on embryo development, we staged the embryos from all nests with data loggers. Given the large number of eggs in each plot, we used a simple staging table in which embryos were divided in the 5 stages described above according to Chacón et al. (2007). These stages corresponded roughly with those of Crastz (1982) as follows: Stage I: Stages 1-10 (appearance of eye considered Stage II); Stage II: Stages 11-20 (appearance of pigmentation considered Stage III); Stage III: Stages 21-28 (onset of vitelline sac reabsorption considered Stage IV); Stage IV: up to hatching.

Mean incubation temperatures were significantly lower in nests with development compared to nests without development, i.e. $34.97\left(\mathrm{CI}_{95 \%} 34.47-35.46^{\circ} \mathrm{C}\right)$ and $37.08^{\circ} \mathrm{C}\left(\mathrm{CI}_{95} \% 36.59-37.58^{\circ} \mathrm{C}\right)$, respectively $(t=$ $6.27, \mathrm{p} \leq 0.0001)$. The highest developmental stage reached within a nest was inversely related to mean incubation temperature (regression analysis: $r^{2}=0.706$, $\mathrm{p} \leq$ 0.0001, Fig. 7). The highest developmental stage reached was also inversely proportional to the total number of days with incubation temperatures $>35^{\circ} \mathrm{C}$ (regression analysis: $\mathrm{r}^{2}=0.804, \mathrm{p} \leq 0.0001$; Table 1 ).

Mean incubation temperatures were also significantly lower within the 5 nests with hatchlings $\left(33.84^{\circ} \mathrm{C}, \mathrm{CI}_{95 \%} 33.24-34.44^{\circ} \mathrm{C}\right.$; Stage 5) compared to nests without $\left(36.20^{\circ} \mathrm{C}, \mathrm{CI}_{95} \% 35.73-36.67^{\circ} \mathrm{C}\right.$; Stages $0-4 ; t=3.98, \mathrm{p} \leq 0.0003)$. The rate of $14.81 \%$ hatching

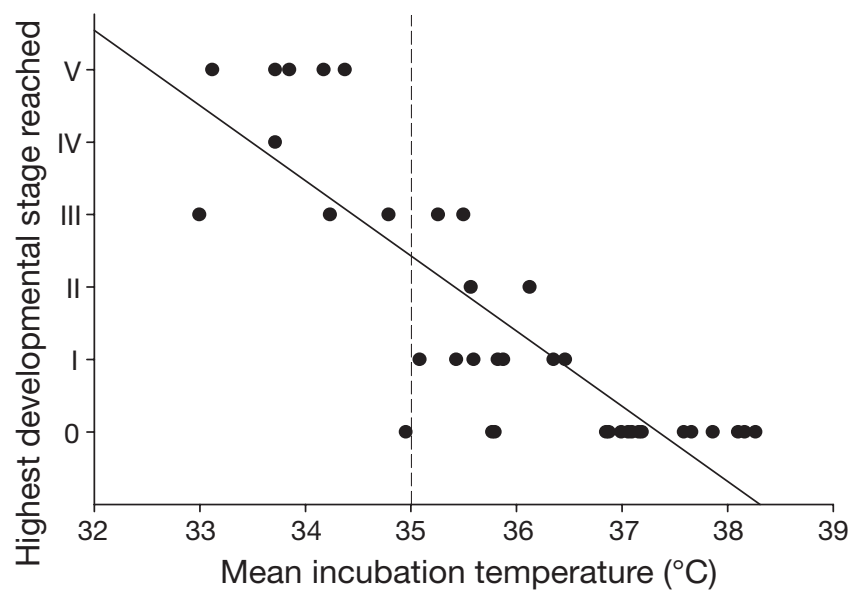

Fig. 7. Last developmental stage reached per nest in relation to mean incubation temperature. Solid line: linear trend. Vertical dashed line: field lethal temperature of $35^{\circ} \mathrm{C}$. Stage 0 : no embryonic development reached; Stage I: 1-25\% egg volume occupied by developing embryo; Stage II: 26-50\%; Stage III: $51-75 \%$, Stage IV: $76-100 \%$; Stage V: hatchlings

success was low within nests with hatchlings (Table 1). The nest with the highest percent emergence of $34.29 \%$ ( $\mathrm{n}=36$ hatchlings from 105 eggs) had the lowest mean incubation temperature.

\section{Embryo development and hatching success in density plots}

A total of 8697 eggs were exhumed from $29 \times 1 \mathrm{~m}^{2}$ plots. Clutch density was too high to tell individual nests apart, which is similar to what was found previously (Cornelius et al. 1991). For this reason we counted all eggs within each plot. Thus, 4183 eggs from 8 plots from the October arribada yielded a density of 522.88 eggs $\mathrm{m}^{-2}$, and 4514 eggs from 21 plots 
Table 1. Mean incubation temperatures per month ( $\left.T_{\text {inc }}\right)$ and per trimester (1st, 2nd, 3rd), number of hatchlings, clutch size, and percent hatching success of the 5 nests that yielded emerging hatchlings. $D=$ number of days for which mean incubation temperature $>35^{\circ} \mathrm{C}$ for successful nests

\begin{tabular}{|c|c|c|c|c|c|c|c|c|c|c|c|}
\hline \multirow[t]{2}{*}{ Month } & \multirow{2}{*}{$\begin{array}{c}\text { Mean } \\
T_{\text {inc }}\left({ }^{\circ} \mathrm{C}\right)\end{array}$} & \multicolumn{8}{|c|}{ - Nests with hatchlings - } & \multirow{2}{*}{$\begin{array}{l}\text { Clutch } \\
\text { size }\end{array}$} & \multirow{2}{*}{$\begin{array}{c}\text { Hatching } \\
\text { success }(\%)\end{array}$} \\
\hline & & $D$ & $1 \mathrm{st}$ & $D$ & 2nd & $D$ & 3rd & $D$ & Hatchlings & & \\
\hline October & 34.17 & 10 & 33.76 & 0 & 33.94 & 2 & 34.81 & 8 & 19 & 100 & 19.00 \\
\hline November & 33.71 & 15 & 30.60 & 0 & 33.41 & 0 & 37.13 & 15 & 3 & 81 & 3.70 \\
\hline November & 33.85 & 16 & 31.44 & 0 & 34.06 & 1 & 36.05 & 15 & 5 & 94 & 5.32 \\
\hline November & 33.12 & 7 & 30.86 & 0 & 33.46 & 0 & 35.02 & 7 & 36 & 105 & 34.29 \\
\hline December & 34.37 & 17 & 33.32 & 0 & 34.19 & 2 & 35.61 & 15 & 10 & 85 & 11.76 \\
\hline Average & 33.84 & 13 & 32.00 & 0 & 33.81 & 1 & 35.72 & 12 & 14.6 & 93.00 & 14.81 \\
\hline
\end{tabular}

from the November arribada yielded a density of 214.95 eggs $\mathrm{m}^{-2}$. Taking the average clutch size as 100 eggs $\left(\mathrm{CI}_{95 \%}\right.$ 94.55-105.45; $\mathrm{n}=41$ nests with data loggers), the nest densities for October and November plots were 5.23 and 2.15 clutches $\mathrm{m}^{-2}$, respectively.

There was no embryo development in most nests (92.83 and $88.99 \%$ of eggs lacked any visible development in October and November, respectively). Within nests that had embryonic development, a significantly greater percentage of developing eggs from November nests resulted in hatchlings $(97.79 \%$ or 486 hatchlings; $t=2.1161, \mathrm{p}=0.375$ ) compared to those from October nests $(21.67 \%$ or 65 hatchlings). Likewise, the hatching success rate for November nests was significantly higher $\left(10.77 \%, \mathrm{CI}_{95 \%} 7.17-30.32 ; t=2.8196\right.$, $\mathrm{p}=0.006)$ than for October nests $\left(1.55 \%, \mathrm{CI}_{95 \%}\right.$ $0.94-4.53)$. Mean hatching rate for both months combined was $6.34 \%$.

\section{DISCUSSION}

Most studies of incubation temperature, sea turtle embryo development and TSD are concerned with the potential feminization of sea turtle populations in the face of global warming temperatures. The reason for this is that elevated temperatures tend to promote skewed sex ratios toward a female bias (Wibbels 2003, 2007), which may curtail the reproductive potential of a population by decreasing the number of male turtles (Fuentes et al. 2010). However, our data indicate that an issue of greater concern at Ostional Beach is that incubation temperatures measured in the dry season are not only on the high end of the TRT, above PT, but are near the upper limit of the TTR and surpass lethal temperatures, leading to developmental arrest and to the death of olive ridley embryos. Indeed, our data are consistent with a field lethal incubation temperature of $\sim 35^{\circ} \mathrm{C}$ when most nests yielded embryos with little or no appreciable development. This effect of temperature was most conspicuous in January nests when development was negligible and no hatchlings were produced. This field lethal incubation temperature is consistent with the lethal temperature determined under laboratory conditions for sea turtle embryos when eggs are incubated at a constant temperature (Ackerman 1997). Because our study focused only on a part of the year when incubation temperatures were significantly elevated, we cannot conclude that the historically low hatching rates documented at Ostional are due to lethal incubation temperatures. However, our study supports the claims of the Ostional community that during the dry season hatchling production is nearly zero (Cornelius et al. 1991). Our study provides empirical evidence that this lack of hatchling production during the dry months is due to the lethal effect of temperature.

Although both humidity and temperature constitute powerful regulators of embryonic development (Miller 1985), we believe that temperature plays a more significant role in this study. The reason is that lethal temperatures from laboratory studies are derived from clutches incubated in hydric environments that promote optimal embryo development (e.g. McCoy et al. 1983, Wibbels et al. 1998). Under these conditions, high embryo mortality is observed when constant incubation temperatures extend beyond TTR (Yntema \& Mrosovsky 1980, Ackerman 1997).

Interestingly, incubation temperature seems to exhibit a tonic effect on embryo mortality and development on the high end of the TTR given that it is the time spent at high temperatures and above $35^{\circ} \mathrm{C}$ that determines embryo arrest and death and not the mere fact of reaching this temperature. This indicates that embryos have physiological mechanisms that allow them to withstand exceedingly high temperatures, and that these mechanisms will fail if temperatures do not decrease below the lethal limit. Presumably, cooling periods (e.g. rain) may rescue embryos at risk of overheating. This observation supports the idea of developing artificial ways to cool down incubating nests during the dry months by providing them with irrigation or shading (Cornelius et al. 1991) to increase hatchling production during those months, if desirable. 
Olive ridleys, like other sea turtle species, are known to nest year round in Costa Rica. Indeed, small arribadas and solitary nesting have been documented for the olive ridley on the Pacific coast every month of the year, with the larger arribadas occurring between August and November (Hughes \& Richard 1974, Cornelius 1986). Although far less abundant, other turtle species such as greens and leatherbacks also exhibit year round nesting, with a discrete peak reproductive window including the months between October and March (Cornelius 1986, Reina et al. 2002). These months coincide with some of the hottest, driest months of the year. This presumes a similar scenario for these species as in our study with the consequent detrimental impact on embryo development. However, both leatherbacks and greens exhibit strategies that allow them to nest during the most thermally challenging months of the year. For instance, although leatherbacks prefer to nest in the open beach, they do so at a greater depth than ridleys (Binckley et al. 1998), whereas greens prefer to nest in the vegetation where temperatures are lower (Cornelius 1976, 1986), thus escaping the detrimental effect of the high temperatures. In contrast, ridleys prefer to nest in the open beach (Hinestroza \& Páez 2001) and the top of their nests is at an average $22 \mathrm{~cm}$ from the surface (Vega \& Robles 2005), which makes their nests more susceptible to the high temperatures of the dry season. As such, the high embryo mortality of ridley embryos during the dry months explains the selection pressure of this species to time the bulk of their reproductive effort to coincide with the rainy season when lower incubation temperatures are more favorable for development.

Rainfall was virtually absent during our study with only 2 brief periods of significant rain, both recorded in early and late November. We observed a decrease in incubation temperature associated with these periods of rain. This cooling effect of rain has been recognized in many studies (Leslie et al. 1966, Godfrey et al. 1996, Binckley et al. 1998, Matsuzawa et al. 2002, Houghton et al. 2007). Thus, the lack of rainfall likely led to the exceedingly high incubation temperatures recorded during the study period, which reached their zenith during January and February when nests incubated at mean temperatures $>36^{\circ} \mathrm{C}$ and embryo development was curtailed. This situation was expected to continue throughout the rest of the dry season. Would hatching rates recover to match those of solitary nesting rates of $59 \%$ and higher for olive ridley nests (Francia 2004, Lopez-Castro et al. 2004) during the next rainy season when incubation temperatures were expected to decrease? We believe that this is unlikely. Although our data supports a preponderant effect of temperature driving embryo mortality at Ostional, hatching rates at Costa Rican arribada beaches have been historically low
(Cornelius et al. 1991, Valverde et al. 1998, Fonseca et al. 2009), even during the rainy months. Factors such as density-dependent effects and high microorganism load due to decomposing organic matter and associated oxygen depletion in the nest (Valverde et al. 1998, ClusellaTrullas \& Paladino 2007, Honarvar et al. 2008, Fonseca et al. 2009) are thought to be involved in the embryonic death in Costa Rican arribada beaches during the rainy months. Thus, our study highlights the importance of continuing research focusing on the mechanisms that drive embryo mortality under various rainfall, temperature and nest density conditions and over seasons to verify whether our results are typical of these beaches.

The large differences between cooler controls and warmer study nests in the present study indicate that metabolic heating occurred during the incubation periods for nests laid in November and January. November arribada nests exhibited metabolic heating that was primarily of embryological origin. Embryonic metabolic heating occurs during the second half of embryo development, especially during the last trimester (Maxwell et al. 1988, Maloney et al. 1990, Godfrey et al. 1997, Broderick et al. 2001). Thus, temperature differences between controls and nests increase with the progression of the incubation period, as observed in December when November nests incubated. However, in the case of January, nests embryo development was minimal while incubation temperatures were higher in nests than in controls. Adult and larval insects, fungi, and microorganisms have been associated with dead turtle eggs and dead hatchlings at Ostional (Madden et al. 2008), and large quantities of these organisms may contribute to metabolic heating. Thus, we feel that the difference in temperatures between nests and controls in January and February is most likely due to microbial, or decomposer, metabolic heating.

Lastly, our exhumation plots yielded additional empirical embryo development data and support our findings of low development and hatching rates from marked nests. The higher hatching rates in exhumation plots from November could be attributable to a lower nest density than October nests as it has been reported that density-dependent effects may impair embryo development (Honarvar et al. 2008). Thus, it is tempting to suggest that, under in situ conditions at Ostional, density-dependent effects that limit embryo development manifest at nest densities $>2$ nests $\mathrm{m}^{-2}$, though this cannot be determined from our study due to the overriding effect of the high incubation temperatures.

\section{SUMMARY}

Our results are consistent with a field lethal incubation temperature of $35^{\circ} \mathrm{C}$ for olive ridley embryos. Our 
data suggest that at Ostional, high incubation temperature is the primary factor limiting embryo development during the dry season. Our results indicate that nests laid during arribadas are vulnerable to short term weather fluctuations, especially droughts. Without the rain's cooling effect, metabolic heating within densely spaced nests from arribadas may push the already high incubation temperatures towards and beyond the upper limit of the TTR, thus disrupting or terminating embryo development or producing single sex clutches. The findings of this study provide a glimpse of the effects of the expected global warming temperatures on sea turtle populations around the world. It has been forecasted that global temperatures may increase by up to $3.5^{\circ} \mathrm{C}$ or more by the year 2100 (IPCC 2007). According to our data, not only is feminization of sea turtle populations possible, but the increase in embryo mortality due to lethal field temperatures may be a reality for some populations. Ostional Beach, and perhaps other arribada beaches in the Eastern Pacific, seem particularly poised to suffer the detrimental effects of global warming. Finally, it is important to emphasize that this study was conducted during the dry season, a time characterized by high temperatures, low precipitation and lower nesting relative to the peak nesting months. Extension of this work to the rainy months is essential to obtain an improved understanding of the mechanisms leading to the high embryo mortality at arribada beaches.

Acknowledgements. We thank L. S. Brenes (Administrator of the Ostional National Wildlife Refuge), the Tempisque Conservation Area, and the Costa Rican Ministry of the Environment and Energy for their support and for providing the permits to conduct this research. We also thank the people of Ostional for their assistance and support during the field work. L. G. Fonseca and 3 anonymous reviewers offered valuable criticism to this manuscript. D. Solís kindly generated Fig. 1. Finally, we thank the many volunteers who assisted with data collection. This research was funded by the Marine Turtle Conservation Program of the USFWS (98210-8-G515). This study was conducted under Southeastern's IACUC permit \#004.

\section{LITERATURE CITED}

Abreu-Grobois A, Plotkin PT (2008) Lepidochelys olivacea. In: IUCN 2009. IUCN Red List of Threatened Species. Version 2009.1, available at www.iucnredlist.org

Ackerman RA (1997) The nest environment and embryonic development of sea turtle. In: Lutz PL, Musick JA (eds) The biology of sea turtles. CRC Press, Boca Raton, FL, p 83-106

Arauz RM, Vargas R, Naranjo I, Gamboa C (1998) Analysis of the incidental capture and mortality of sea turtles in the shrimp fleet of Pacific Costa Rica. In: Epperly SP, Braun J (compilers) Proc 17th Annu Sea Turtle Symp. NOAA Tech Memo NMFS-SEFSC-415, p 1-5

Arauz R, Rodriguez O, Vargas R, Segura A (1999) Incidental capture of sea turtles by Costa Rica's longline fleet. In: Kalb HJ, Wibbels T (compilers) Proc 19th Annu Symp Sea
Turtle Biol Conserv. NOAA Tech Memo NMFS-SEFSC443, p 62-64

Bernardo J, Plotkin PT (2007) An evolutionary perspective on the arribada phenomenon and reproductive behavioral polymorphism of olive ridley sea turtles (Lepidochelys olivacea). In: Plotkin PT (ed) Biology and conservation of ridleys sea turtles. Johns Hopkins University Press, Baltimore, MD, p 59-87

Binckley CA, Spotila JR, Wilson KS, Paladino FV (1998) Sex determination and sex ratios of Pacific leatherback turtles, Dermochelysc oriacea. Copeia 1998:291-300

Broderick AC, Godley BJ, Hays GC (2001) Metabolic heating and the prediction of sex ratios for green turtles (Chelonia mydas). Physiol Biochem Zool 74:161-170

Campbell LM (1998) Use them or lose them? Conservation and the consumptive use of marine turtle eggs at Ostional, Costa Rica. Environ Conserv 25:305-319

Campbell LM, Haalboom BJ, Trow J (2007) Sustainability of community-based conservation: sea turtle egg harvesting in Ostional (Costa Rica) ten years later. Environ Conserv 34:1-10

Chacón D, Sánchez J, Calvo JJ, Ash J (2007) Manual para el manejo y conservación de las tortugas marinas en Costa Rica con énfasis en la opercaión de proyectos en playa y viveros. Sistema Nacional de Areas de Conservación, Ministerio de Ambiente y Energía, San José

Clusella-Trullas S, Paladino FV (2007) Micro-environment of olive ridley turtle nests deposited during an aggregated nesting event. J Zool 272:367-376

Cornelius SE (1976) Marine turtle nesting activity at Playa Naranjo, Costa Rica. Brenesia 8:1-27

Cornelius SE (1986) The sea turtles of Santa Rosa National Park. Fundación de Parques Nacionales, Madrid

Cornelius SE, Ulloa MA, Castro JC, Mata del Valle M, Robinson DC (1991) Management of olive ridley sea turtles (Lepidochelys olivacea) nesting at Playas Nancite and Ostional, Costa Rica. In: Robinson JG, Redford KH (eds) Neotropical widlife use and conservation. University of Chicago Press, Chicago, IL, p 111-135

Cornelius SE, Arauz R, Fretey J, Godfrey MH, Marquez-M. R, Shanker K (2007) Effect of land based harvest of Lepidochelys. In: Plotkin PT (ed) Biology and conservation of ridley sea turtles. Johns Hopkins University Press, Baltimore, MD, p 231-251

Crastz F (1982) Embryological stages of the marine turtle Lepidochelys olivacea (Eschscholtz). Rev Biol Trop 30: 113-120

Eckrich CE, Owens DW (1995) Solitary versus arribadas nesting in the olive ridley sea turtles (Lepidochelys olivacea): a test of the predator-satiation hypothesis. Herpetologica 51: 349-354

> Ewert MA, Jackson DR, Nelson CE (1994) Patterns of temperature-dependent sex determination in turtles. J Exp Zool 270:3-15

> Fonseca LG, Murillo GA, Guadamúz L, Spínola RM, Valverde RA (2009) Downward but stable trend in the abundance of arribada olive ridley (Lepidochelys olivacea) sea turtles at Nancite Beach, Costa Rica for the period 1971-2007. Chelonian Conserv Biol 8:19-27

Francia AG (2004) Predación y eclosión en nidos solitarios y de arribadas de tortugas loras (Lepidochelys olivacea), baulas (Dermochelys coriacea) y negras (Chelonia mydas agassizi) en las playas Nancite y Naranjo e incidencia humana sobre las anidaciones de tortugas marinas en playa Junquillal, Costa Rica. Programa Regional en Manejo de Vida Silvestre para Mesoamérica y el Caribe. MSc thesis, Universidad Nacional, Heredia 
Frazier J, Arauz R, Chevalier J, Formia A and others (2007) Human-turtle interactions at sea. In: Plotkin PT (ed) Biology and conservation of ridley sea turtles. Johns Hopkins University Press, Baltimore, MD, p 253-296

Fuentes MMPB, Hamann M, Limpus CJ (2010) Past, current and future thermal profiles of green turtle nesting grounds: implications from climate change. J Exp Mar Biol Ecol 383:56-64

Godfrey MH, Barreto R, Mrosovsky N (1996) Estimating past and present sex ratios of sea turtles in Suriname. Can J Zool 74:267-277

- Godfrey MH, Barreto R, Mrosovsky N (1997) Metabolically generated heat in sea turtles nests and its potential effect on the sex ratio of hatchlings. J Herpetol 31:616-619

Hinestroza LM, Páez VP (2001) Anidación y manejo de la tortuga golfina (Lepidochelys olivacea) en la Playa La Cuevita, Bahía Solano, Chocó, Colombia. Cuad Herpetol 14: 131-144

Honarvar S, O'Connor MP, Spotila JR (2008) Density-dependent effects on hatching success of the olive ridley turtle, Lepidochelys olivacea. Oecologia 157:221-230

Hope RA (2002) Wildlife harvesting, conservation and poverty: the economics of olive ridley egg exploitation. Environ Conserv 29:375-384

$>$ Houghton JDR, Myers AE, Lloyd C, King RS, Isaacs C, Hays GC (2007) Protracted rainfall decreases temperature within leatherback turtle (Dermochelys coriacea) clutches in Grenada, West Indies: ecological implications for a species displaying temperature dependent sex determination. J Exp Mar Biol Ecol 345:71-77

Hughes DA, Richard JD (1974) The nesting of the Pacific ridley turtle Lepidochelys olivacea on Playa Nancite, Costa Rica. Mar Biol 24:97-107

IPCC (Intergovernmental Panel on Climate Change) (2007) Climate change 2007: summary for policy makers. Synthesis Report. IPPC, Valencia, p 22

Janzen FJ, Paukstis GL (1991) Environmental sex determination in reptiles: ecology, evolution, and experimental design. Q Rev Biol 66:149-179

Leslie AJ, Penick DN, Spotila JR, Paladino FV (1966) Leatherback turtle, Dermochelys coriacea, nesting and nest success at Tortuguero, Costa Rica, in 1990-1991. Chelonian Conserv Biol 2:159-168

Lopez-Castro MC, Carmona R, Nichols WJ (2004) Nesting characteristics of the olive ridley turtle (Lepidochelys olivacea) in Cabo Pulmo, southern Baja California. Mar Biol 145:811-820

> Madden D, Ballestero J, Calvo C, Carlson R, Christians E, Madden E (2008) Sea turtle nesting as a process influencing a sandy beach ecosystem. Biotropica 40:758-765

Maloney JE, Darian-Smith C, Takahashi Y, Limpus CJ (1990) The environment for development of the embryonic loggerhead turtle (Caretta caretta) in Queensland. Copeia 1990:378-387

Márquez-M. R, Peñaflores C, Vasconcelos J (1996) Olive ridley turtles (Lepidochelys olivacea) show signs of recovery at La Escobilla, Oaxaca. Mar Turtle Newsl 73:5-7

Matsuzawa Y, Sato K, Sakamoto W, Bjorndal KA (2002) Seasonal fluctuations in sand temperature: effects on the incubation period and mortality of loggerhead sea turtle (Caretta caretta) pre-emergent hatchlings in Minabe, Japan. Mar Biol 140:639-646

Maxwell JA, Motara MA, Frank GH (1988) A micro-environmental study of the effect of temperature on the sex-ratios of the loggerhead turtle, Caretta caretta, from Tongaland, Natal. S Afr J Zool 23:342-350

Editorial responsibility: Matthew Godfrey, Beaufort, North Carolina, USA
McCoy CJ, Vogt RC, Censky EJ (1983) Temperature-controlled sex determination in the sea turtle Lepidochelys olivacea. J Herpetol 17:404-406

> Merchant-Larios H, Ruiz-Ramirez S, Moreno-Mendoza N, Marmolejo-Valencia A (1997) Correlation among thermosensitive period, estradiol response, and gonad differentiation in the sea turtle, Lepidochelys olivacea. Gen Comp Endocrinol 107:373-385

Miller JD (1985) Embryology of marine turtles. In: Gans C, Billett F, Maderson FPA (eds) Biology of the reptilia, development A. Wiley, New York, NY, p 269-328

Miller JD (ed) (1997) Reproduction in sea turtles. The biology of sea turtles. CRC Press, Boca Raton, FL, p 51-81

- Mrosovsky N (1994) Sex ratios of sea turtles. J Exp Zool 270: $16-27$

> Mrosovsky N, Pieau C (1991) Transitional range of temperature, pivotal temperature and thermosensitive stage for sex determination in reptiles. Amphib-reptil 12:169-179

Pandav B, Choudhury BC, Kar CS (1994) Discovery of a new sea turtle rookery in Orissa, India. Mar Turtle Newsl 67: $15-16$

Plotkin PT (2007) Olive ridley sea turtle (Lepidochelys olivacea). Five-year review: summary and evaluation. USFWS, Silver Spring, MD and NMFS, Jacksonville, FL

Reina RD, Mayor PA, Spotila JR, Piedra R, Paladino FV (2002) Nesting ecology of the leatherback turtle, Dermochelys coriacea, at Parque Nacional Marino Las Baulas, Costa Rica: 1988-1989 to 1999-2000. Copeia 2002:653-664

> Richard JD, Hughes DA (1972) Some observations of sea turtle nesting activity in Costa Rica. Mar Biol 16:297-309

Shanker K, Pandav B, Choudhury BC (2004) An assessment of the olive ridley turtle (Lepidochelys olivacea) nesting population in Orissa, India. Biol Conserv 115:149-160

Valverde RA, Gates CE (1999) Population surveys on mass nesting beaches. In: Eckert KL, Bjorndal KA, AbreuGrobois FA, Donnelly M (eds) Research and management techniques for the conservation of sea turtles. IUCN/SSC Marine Turtle Specialist Group Publication No. 4, Washington, DC, p 56-60

Valverde RA, Cornelius SE, Mo CL (1998) Decline of the olive ridley sea turtle (Lepidochelys olivacea) nesting assemblage at Nancite beach, Santa Rosa National Park, Costa Rica. Chelonian Conserv Biol 3:58-63

Vega AJ, Robles Y (2005) Descripción del proceso de anidación y biometría de hembras, huevos y nidos en tortuga golfina Lepidochelys olivacea (Eschscholtz, 1829) en Isla de Cañas, Pacífico panameño. Tecnociencia 7:43-55

Wallace BP, Sotherland PR, Spotila JR, Reina RD, Franks BF, Paladino FV (2004) Biotic and abiotic factors affect the nest environment of embryonic leatherback turtles, Dermochelys coriacea. Physiol Biochem Zool 77:423-432

Wibbels T (2003) Critical approaches to sex determination in sea turtles. In: Lutz PL, Musick JA, Wyneken J (eds) The biology of sea turtles II. CRC Press, Boca Raton, FL, p 103-134

Wibbels T (2007) Sex determination and sex ratios in ridleys turtles. In: Plotkin PT (ed) Biology and conservation of ridley sea turtles. Johns Hopkins University Press, Baltimore, MD, p 167-189

Wibbels T, Rostal DC, Byles R (1998) High pivotal temperature in the sex determination of the olive ridley sea turtle from Playa Nancite, Costa Rica. Copeia 1998: 1086-1088

Yntema CL, Mrosovsky N (1980) Sexual differentiation in hatchling loggerheads (Caretta caretta) incubated at different controlled temperatures. Herpetologica 36:33-36 